\title{
THE LOGIC OF COLLECTIVE BARGAINING AND ARBITRATION
}

\author{
Alexander Hamilton Frey*
}

Arbitration is regarded by some as a panacea for all labor controversies. To others arbitration of labor disputes is anathema. That there should be this extreme conflict of reaction is not surprising, for immoderate opinions are most common where there is least understanding, and few have made a searching inquiry into the nature of collective bargaining, without which the role of arbitration cannot be fully understood. The purpose of this article is to explore the thesis that (I) collective bargaining within the realm of labor relations is vital to the perpetuation of the American system of free enterprise, and (2) arbitration is an essential element in the successful functioning of the process which we have come to know as collective bargaining. Three fundamental assumptions underlie this thesis: first, freedom of enterprise-as contrasted with dictation by government or the state-is the basic American procedure for determining the uses to which the labor or the property of an individual are to be subjected; second, the traditional procedure of free enterprise whereby these uses are determined is a process of bargaining between individuals or groups of individuals; third, conditions which threaten the permanence of, or which seriously curtail, this bargaining process are dangerous encroachments upon our system of freedom of enterprise.

\section{I}

\section{The Significance of Collective Bargaining to Freedom of Enterprise}

"Bargaining," as that term is used herein, is the process whereby two persons with opposing interests arrive at, or attempt to arrive at, the terms of a sale; $;^{1}$ where two or more persons act as a unit on one or both sides the process is referred to as "collective bargaining."

Whether the subject-matter of the transaction be property or labor," a "bargain-

* A.M. 1920, Columbia Univ.; A.B. 1919, LL.B. 1921, J.S.D. 1925, Yale Univ. Professor of Law, Univ. of Pennsylvania Law School. Formerly Public Member, National War Labor Board, and Vice. Chairman, Third Regional War Labor Board. Author, Cases and Statutes on Business Association: (1935), CASEs oN LABOR LAW (194I), and contributor to legal and other periodicals. Frequent arbitrator of labor disputes.

2 "Sale" is used herein in a broad sense to include transactions transferring use and possession as well as ownership, and also to include transactions from which there emerge terms embodied not in a contract but in schedules, standard clauses or provisions, rules, codes, etc.

'It has frequently been said that the labor of a human being is not a commodity. This statement means that when one person acquires the use of another's services there are moral and ethical factors involved that are not present in the sale of lands, chattels, animals or credit. Nevertheless there is no essential difference between the processes whereby the terms of a sale and the terms of an employment relationship are arrived at, and in both instances the term "bargaining" is used to describe the negotiations, if any. 
ing" situation does not obtain between a buyer and a seller unless each is able to force upon the other some concession, some abandonment of a preferred position. The seller can exert very little pressure with respect to the terms of the sale unless there is some degree of scarcity, some limitation upon the supply of that which he seeks to sell. This is the first essential of "bargaining power." If the seller is offering something for which the buyer is willing to pay $a$ price, i.e., which it is advantageous to the buyer to purchase at some price, the ultimate price which the seller receives, whether he controls all or only a fraction of the supply, depends upon the respective resources with which each of the parties can withstand a deadlock. In other words, if the seller has no capital, if he must sell to live, then-even in the extreme case where he controls the entire suppIy-he must accept the best terms offered, however far below what he regards as a "fair" price. Without some resources at the seller's command, there is no element of "give and take" in the situation. This is the second essential of "bargaining power."

The Industrial Revolution, i.e., the mechanization of the processes of production and the introduction of the factory system, brought about conditions which have terminated the ability of all but the most highly skilled workers to bargain individually with their employers on a basis of equality. In earlier times employer and employee belonged to the same community, attended the same church, participated in the same political activities, and were not very far removed in the economic scale. There was no great surplus of labor; if the terms of employment offered to a given employee by his employer were unsatisfactory, more likely than not the parties would talk face to face and reach an accord. Or if the terms were regarded by the employee as utterly unreasonable, he could do odd jobs for others, farm on his own land, and look forward to the security of at least subsistence for his family and himself for an indefinite period. And eventually either the employer would feel the need of his services sufficiently to modify his former offer, or the employee would find other satisfactory work in the same community.

But with the coming of the Industrial Revolution all this was changed. Great cities developed which were the centers of the factory system. The individual worker and his employer grew farther and farther apart socially and economically. The favorable atmosphere for personal conferences and adjustment of disputes disappeared. Mass-production methods resulted in huge concentrations of labor and in a great increase in the percentage of jobs not requiring skilled work. Thus unskilled workers are today the vast majority of those employed or seeking employment, and their labor has little or no element of scarcity. Moreover, whether skilled or unskilled, the individual factory worker normally has no capital with which to withstand a "buyers' strike." He owns no land, has no tools, and hence has few resources with which he and his family can hope to survive an extended deadlock with his employer over terms of employment. Furthermore, labor cannot be preserved and held for a more favorable market: a worker cannot tomorrow sell 
today's unexpended labor. Nor does the labor of an individual worker have the fluidity that attaches to most commodities or to credit seeking a market: a workman and his family are effectively bound to a limited geographical area of job opportunity. ${ }^{3}$

In short, under modern industrial conditions the individual worker is powerless to bargain with his employer with respect to the terms of his employment. Acting alone, he has no practical alternative but to accept the terms offered to him. But through unionization the individual worker may be enabled to secure at least a measure of the two essentials of bargaining power. In the first place, unions provide a medium for concerted action by which the supply of labor available to an employer may be restricted, so that even unskilled labor in an era of unemployment will have some scarcity value. Second, unions constitute a potential source of that minimum of capital which the individual worker must have if he is to be able to resist at all when deadlocked with his employer over terms and conditions of employment.

In any given transaction there may be a considerable disparity between the bargaining powers of buyer and seller without any noteworthy effect upon our economy. Some inequality of bargaining power is the rule rather than the exception, ${ }^{4}$, and our free-enterprise system does not concern itself with minor advantages that may accrue to the stronger party. But if there is an absence of bargaining power, or if a pronounced disparity of bargaining power develops as to a significant class of buyers (or sellers), then experience has taught that government will intervene, either by dictating to buyer and seller the terms of the sale (thus removing it from the traditional bargaining process of free enterprise), or by attempting to improve the bargaining power of the weaker side, so that the bargaining process, and the free-enterprise system, may continue to function without the injustice inherent in inequality.

If it be conceded that under modern industrial conditions the individual worker, acting alone, has little or no bargaining power, then it must be recognized that he will endeavor to foster his interests by acting in concert with his fellow workers. And if workers fail in their efforts to bring themselves within the framework of our free-enterprise system by achieving collective bargaining power-and they had failed signally prior ${ }^{6}$ to the passage of the National Labor Relations Act in $1935^{7}-$

${ }^{2}$ For an elaboration of this analysis see Frey, CASES ON LABOR LAw (1941) I-6.

- For equality of bargaining power between buyer and seller there would have to be at least (a) equality of desire on the part of the buyer to buy from the seller, and on the part of the seller to sell to the buyer that which is the subject-matter of the transaction (i.e., the opportunities for the buyer to buy and the seller to sell elsewhere would have to be equal); (b) equality of resources of buycr and seller with which to withstand a deadlock; and (c) equality of pertinent knowledge and of skill in negotiating.

'Infancy law, usury statutes, and fiduciary standards are traditional examples. When emergency conditions disrupt the normal balance of bargaining power, temporary controls (as on rent, commodities, wages, etc.) are at times instituted.

- In 1935 the American Federation of Labor, after more than fifty years of existence, had less than 3,000,000 members, the C.I.O. was non-existent, and apart from the Railroad Brotherhoods there were no other nationally significant labor organizations.

49 Stat. 449 (1935), 29 U. S. C. \$15I et seg. (1940). 
then governmental intervention to promote the interests of a group of such proportions may be anticipated. In a society such as ours, dedicated to the perpetuation of a system of free enterprise, the function of government is not to displace that system but to protect it. Accordingly, the government has thus far sought to safeguard the individual worker not by dictating the wages to be paid to him, but by facilitating the development of organizations through which he may achieve the only kind of realistic freedom of enterprise available to him, namely, collective bargaining.

There can be little doubt that if the collective-bargaining endeavor fails significantly to bring about substantial equality of bargaining power between employers and employees, ${ }^{8}$ then the government will be forced to attempt to aid whichever is the weaker side by dictating wages to be paid and received. Dictation by government of the terms of any sale (even the establishment of "floors" and "ceilings") tends to set off a chain of governmental actions which increasingly restrict the areas of free enterprise. This is particularly true with respect to the establishment of labor costs by governmental fiat, for in order to effectuate its wage policy the government would find it had also to concern itself with other costs and with prices, which in turn would involve profits, and the investment of capital, and the use of property, and the myriad decisions which are now reached by the traditional process of free bargaining.

If the alternatives are substantial equality of bargaining power for the individual employee in relation to his employer through the device of collective bargaining, or governmental dictation of wages and a congeries of related interests, then collective bargaining emerges as a potential bulwark of the free-enterprise system, and labor unions are seen as organizations having significance to society as well as to their own members. An understanding of the factors without which collective bargaining cannot succeed is of the utmost importance to the preservation of our national economy.

\section{II}

\section{The Prerequisites of Collective Bargaining}

Since the individual worker can bring himself within the framework of our freeenterprise system only by bargaining collectively, the first essential is that employers shall bargain with their employees only on a collective and not on an individual basis. Even though a group of workers form an organization and agree to negotiate only as a unit with a given employer or potential employer, they do not in fact achieve any bargaining power with reference to that employer so long as he is able to obtain an adequate supply of competent employees on his own terms by dealing individually with other, unorganized workers. Hence, if there is a sincere desire to

\footnotetext{
- Collective bargaining might fail either because employers succeed in reducing unions to an impotent state, or because unions become so powerful and arrogant as to make a mockery of bargaining negotiations.
} 
have labor relations determined by a genuine bargaining process, and not by governmental fiat, it is necessary either that employers voluntarily refrain from dealing with individual employees for their labor except on terms that have emerged from collective-bargaining negotiations, or that employers be precluded from engaging in such individual transactions by virtue of the organization of substantially all available employees as members of one or more labor unions through which they will bargain only collectively.

The suggested self-restraint is hardly likely to occur: each employer (even corporations employing huge aggregates of workers) will discount the danger of eventual governmental intervention on a national scale because of the absence of genuine bargaining in his plant; each employer will convince himself that the terms and conditions of employment which he will unilaterally establish if the opportunity presents itself are fair and reasonable. Accordingly, it is difficult to escape the conclusion that bargaining as to labor relations can exist only if employers cannot obtain adequate supplies of labor except by first negotiating terms and conditions of employment with an association of workers organized to bargain collectively.

It must be borne in mind that, just as in an ordinary sale there is always a specific subject-matter of the bargain, so in collective bargaining the bargaining is as to the terms and conditions of employment of the employees in a given bargaining unit. A bargaining unit is not a union; it is a group of jobs. It may be the jobs connected with a particular machine or operation; it may be the jobs of a particular craft, such as painters; it may be the jobs in a particular department of a plant; it may be clerical jobs or production jobs; it may be all non-supervisory jobs in a given plant or in all the plants of the employer. Collective bargaining cannot proceed until the bargaining unit has been established, whether by prior practice or custom, decision of an administrative agency, or agreement of the parties. With reference to a given bargaining unit, there may be more than one union to which divergent groups of the available workers belong. If so, the employer will have a choice of organized sources of his labor supply with which to bargain collectively, ${ }^{9}$ unless the operation of a labor relations statute controls his choice.

Even if the employer has, however, no choice but to deal with one union representing all of his employees or potential employees in a given bargaining unit, this does not place the employer in the unfair position of a would-be buyer of a commodity which has been monopolized by a single seller. The monopolistic commodity seller has many potential buyers to pit against one another, they being unorganized, while each individual buyer has, by hypothesis, no alternate seller with whom to deal. ${ }^{10}$ A labor union is a bargaining agency only if the workers compris-

\footnotetext{
- The existence of such a choice would improve the employer's bargaining position, but it would also involve the risk of "jurisdictional disputes," a form of labor controversy which employers generally decry.

${ }^{10}$ Except where labor is involved, individual sellers and individual buyers are in general deemed to bave comparable bargaining power. Hence, when unions of commodity sellers have been formed, covernment has sought, through anti-trust statutes, to restore the bargaining process by breaking up
} 
ing it act as one man in selling their labor. The difficulty or impossibility which an employer encounters in finding another group of employees, when all are organized, is thus matched by the difficulty or impossibility which the union members, as a unit, encounter in finding another employer. ${ }^{11}$

This unitary aspect of organized workers is an essential element of collective bargaining. There can be no bargaining as to the sale of labor without the right to strike and to lock-out. Unless those available for work in a given bargaining unit are permitted to act in concert in refusing to work on the job or jobs involved in the bargaining unit, and unless the employer is permitted to withhold job opportunities from the members of the bargaining unit as a group, a bargaining condition as to labor relations cannot exist. There are several interesting corollaries to this conclusion. Where a condition of collective bargaining does exist, and the workers in a given bargaining unit embark upon an economic strike, ${ }^{12}$ they ought not to be privileged to exert other economic pressure upon the employer, such as inducing or persuading third persons to cease or refrain from dealing with him, so long as he either does not or cannot obtain labor to replace that of the striking members of the bargaining unit; and a refusal by another employer to employ the strikers while the strike is in progress ought not to be adjudged an unfair labor practice on his part. $^{13}$ So-called "secondary" boycotts and sympathetic strikes are defensible, if at all, only in situations where the conditions of collective bargaining do not exist ${ }^{14}$ or where the strike is provoked by a statutory unfair labor practice of the employer. If, however, the employer replaces the striking members of the bargaining unit with non-union employees, neither the strikers nor the unorganized replacements have any actual bargaining power, and almost inevitably the strikers will attempt to exert other forms of economic pressure upon the employer than the futile withholding of their own services.

Outside the field of labor relations, the equivalent of a strike or a lockout is a normal element in the bargaining process. When buyer $A$ (usually a corporation) is unable to reach an accord with seller $X$ (usually another corporation), buyer $A$ refuses to deal further with seller $X$, or vice versa, and each seeks a seller or a

such combinations. With respect to individual sellers of labor government has attempted, through labor relations statutes, to re-establish the bargaining process by stimulating the development of unions of such sellers.

12 The first element of bargaining equality is therefore present; i.e., the opportunities for the buyer to buy and the seller to sell elsewhere are equal.

${ }^{12} \mathrm{An}$ "cconomic" strike is a strike to force wage or other concessions from the employer which he is not required by law to grant. A strike to induce an employer to abide by the requirements of the National Labor Relations Act (or of some other federal or state labor statute) is commonly referred to as an "unfair labor practice" strike.

${ }^{18}$ By reference to $\$ \$ 2(3), 7,8(I)$ and $8(3)$, this would appear now to be a violation of the National Labor Relations Act.

"In many states there is no local counterpart of the National Labor Relations Act, so that, if interstate commerce is not affected, efforts to form a union and to achieve union recognition may be unsuccessful because no applicable statute deprives the employer of the devices, such as discrimination, which he is privileged at common law to use to thwart the establishment of a collective-bargaining organization among his employees. 
buyer elsewhere. But, as indicated above, when a bargaining impasse occurs between an employer and a union, resulting in a strike or a lockout, there is normally no other seller (i.e., the entire group of workers involved in the bargaining unit) for the buyer (ie., the employer) to turn to, and there is no other employer from whom the workers as a body can obtain employment. The accuracy of this statement is not affected by the fact that a few employees, as individuals, may be able to get some kind of temporary work elsewhere, or that the employer may be able to obtain a trickle of replacements for individual workers. If a strike develops in any plant in which the organized workers constitute a sizable segment of the community, the possibility of other jobs or other workers being obtained on a substantial scale is illusory. Consequently, so long as the deadlock continues, the parties have no alternatives but to wait each other out, or to resume negotiations with each other.

\section{III}

\section{The Public Interest and Collective Bargaining}

The vast body of consumers constituting the public has a very real interest in not having the production of coal, steel, transportation, automobiles, housing, food, and goods and services of many other sorts interrupted while employers and employees engaged in such production slug out their differences over labor relations. Consequently, there are recurring proposals for federal or state legislation aimed at precluding strikes and lockouts; at least in those situations in which the public interest is vitally affected. ${ }^{15}$ But very few members of the public fully comprehend that there is no bargaining power available to most workers in modern industry unless those who can perform the jobs in a given bargaining unit are able to act as one man, and unless that "one man" is given the privilege which any individual has of refusing to work upon the terms or under the conditions proffered. ${ }^{10}$ Too many employers are unmindful of the long-range probability that the absence of collective bargaining as to labor relations will lead to the destruction of their freedom of enterprise and the emergence of some form of state socialism or planned economy.

Here, then, is a perplexing dilemma: strikes which materially affect the production or distribution of essential commodities are inimical to the public interest, but

${ }^{25}$ If once such an inroad on collective bargaining were to be ordained, the omnivorous character of the concept of a "vitally affected" public interest can readily be imagined.

10 This peculiar "unity" feature of collective bargaining causes the scope and the nature of the bargaining unit to be matters of grave significance. Far too little research and objective thinking bas been devoted to 2 study of the appropriateness of various possible bargaining units; the test should be whether the unit chosen will produce the highest degree of bargaining equality with due regard for interrelated interests of others. Industry-wide bargaining may be appropriate in some industries and not in others. Some favor industry-wide bargaining as a method of taking wage rates out of competition, but this is illogical except perhaps as to the establishment of an absolute minimum wage for the industry.

Another most important outgrowth of this "unity" feature of collective bargaining is the matter of esablishing and maintaining democratic procedures not only as to the selection of the union to represent the bargaining unit, but also in the subsequent functioning of that union. Here, too, there has been a haphazard development and a dearth of sound planning. 
legislation which curtails the right to strike, thus in effect eliminating collective bargaining, is not an expedient way to protect the public interest, for the consequences of the cure may too readily be worse than the disease. The situation is not, however, hopeless. There are two relatively untried avenues of approach to the solution of this dilemma. The first lies in an intensive and unremitting search for methods of improving the processes of collective bargaining, thereby bringing about a dramatic decrease in the number of ultimate disagreements, which are the sources of strikes and lockouts. The subject, which is beyond the scope of the present paper, is dealt with elsewhere in this symposium. ${ }^{\mathbf{1 7}}$

Despite the gains that may be expected from wise legislation, from intelligent administrative procedures, ${ }^{18}$ from a far better understanding and acceptance by the parties of their grave responsibility so to conduct themselves as not to endanger the institution of collective bargaining, no doubt there will remain an irreducible minimum of disagreements as to which the disputants are unable to negotiate a mutually acceptable solution. Within this area the protection of the public interest in the avoidance of strikes and lockouts lies in promoting measures which will encourage self-restraint on the part of both employers and organized labor-a not impracticable task, for together these groups constitute a preponderant part of the public.

If a buyer and a seller are fairly evenly matched as to bargaining power, there are several things that may happen: each may make some concessions, may recede somewhat from a preferred position, and thus an agreement may be concluded; or one may ultimately regard the other as so unreasonable as to render further negotiations futile, whereupon they will part company at least for the time being-the equivalent of a strike or a lockout in collective bargaining; or, while unable to agree upon one or more of the terms of their bargain, they may both consent to take a chance within defined limits by submitting the controversy to an impartial third person for final and binding determination. This last procedure is arbitration, and in it lies the major hope of preserving the bargaining process in labor relations, and thus of saving both industry and labor from the evils of domination by officialdom.

\section{IV}

\section{The Fallacy of "Compulsory Arbitration"}

Arbitration of labor disputes is an extension of collective bargaining, ${ }^{10}$ for arbitration of any dispute occurs only when the disputants are relatively equal in bargaining power. If one of the parties to a dispute cannot afford to hold out for his contention, and the other suffers little or nothing by holding out for his, the stronger party, being in a position to prevail without risk of loss, will not agree to arbitrate.

${ }^{17}$ See Fairweather and Shaw, Minimizing Dispures in Labor Contract Negotiations, infra.

13 Governmental measures concerned with promoting conditions within which the traditional bargaining process can operate are desirable, for such measures tend not to displace the frec-enterprise system, but to protect it.

10 Since arbitration is an adjunct of collective bargaining, it cannot be a panacea for all labor troubles. In numerous areas collective bargaining is still non-existent. Many strikes, and much picketing and 
This is the situation in which a worker not fortified by the collective strength of a labor organization finds himself, and there are few, if any, instances in which a dispute over terms of employment between such a worker and his employer has been. submitted to arbitration.

The situation is ripe for arbitration when the parties to a dispute have exhausted their efforts to find a mutually satisfactory settlement, and yet each believes that the risk of detriment sure to result from a prolonged deadlock is greater than the risk of detriment that may result from a not wholly favorable determination of the dispute by an impartial third person. In consenting to arbitrate, the disputants, although unable to agree upon a solution of the substantive issue, do agree upon a procedure for resolving it. When used in this sense, the term "arbitration" refers to a voluntary process; it is a consensual matter, and "compulsory arbitration" is a contradiction in terms.

There is current agitation for legislation that will subject all types of labor disputes to a required, peaceful procedure for reaching a binding decision of the controversy, in place of the war of attrition in which the disputants may now indulge to the detriment of innocent third persons and the public at large as well as themselves. The term most commonly used to summarize this idea is "compulsory arbitration," and this usage will be adopted throughout the remainder of this paper. The waste and the inequities which follow in the train of any prolonged combat over terms or conditions of employment are deplorable. Hence there is a strong appeal in the proposal that such strife be outlawed by compelling the combatants to refrain from direct action against one another, or against third persons, and to abide by the decision of a court or administrative agency, or other impartial body or person, as to the merits of the substantive issues. Despite its appearance of reasonableness, this suggestion of "compulsory arbitration" is open to several objections.

In general, when a status of collective bargaining does exist between employees and their employer, ${ }^{20}$ labor disputes are of two types. There are disputes concerning the interpretation and application of one or more provisions of an unexpired contract between employer and union. These disputes are commonly referred to as "grievances."21 The other class of disputes consists of disagreements as to the terms

\footnotetext{
boycotting, are organizational in character: efforts to bring about the formation of a union, to achieve union recognition, and thus to establish a status of collective bargaining. Here arbitration cannot be the path to peace, for the essential conditions of an agreement even to arbitrate are lacking. The problem is not one of settling a dispute between parties with bargaining power, but of correcting an absence of genuine bargaining. Such an impasse is beyond the scope of arbitration. But here, too, there is room for constructive effort. Intelligent legislation, courageous and enlightened action by labor unions and trade associations, co-operation on the part of influential, public-spirited citizens-by these and other measures much might be done to ninimize the force, violence, coercion and loss which too frequently accompany the effort to achieve a collective-bargaining status for unorganized workcrs, or to cnlarge the jurisdiction of an established union.

${ }^{20}$ Jurisdictional disputes and disputes concerning the formation or recognition of a union are outside the framework of collcctive bargaining.

2x The term "grievances" as herein used is not confined to claims under a trade agreement asserted by or on behalf of an individual employee; the disputed interpretation may relate to an entirc group of employees (e.g., whether a stipulated holiday is with or without pay), or may involve a conflict between the union as such and the employer (c.g., whether the trade agreement permits the revocation of individually signed "check-off" authorizations).
} 
and provisions to be included in an agreement which employer and union have been attempting to negotiate. In this symposium these are termed "contract-negotiation disputes."

There are three outstanding distinctions with respect to these two types of labor disputes. In the case of a grievance, one party accuses the other of having violated the clear meaning or the reasonable interpretation of an agreement which they have jointly negotiated, and the language of the agreement or the proceedings leading up to it provide some standards within which the settlement of the dispute may be confined. The jurisdiction of a court of law or of equity extends to disputes of this category. General or special agreements for the ultimate arbitration of grievances are increasingly common.

But when the controversy is the inability of the parties to achieve a meeting of the minds, their failure to agree at all as to a specific matter (and not merely their lack of agreement as to the application of that to which they did agree), there is no frame of reference guiding or delimiting the search for a solution. Although daily thousands of individuals or corporations are unable to agree upon the terms of a proposed bargain, jurisdiction over such disagreements has not been conferred upon courts of law or equity. Except in a few industries, such as mass transportation, arbitration of labor contract-negotiation disputes is not a frequent occurrence.

The foregoing distinctions reveal that the major failure of collective bargaining is in the realm of contract-negotiation disputes. If legislation were to be enacted for the "compulsory arbitration" of such disputes, by what standards would the issues be decided, especially when a novel demand is made? ${ }^{22}$ Of course, it is conceivable that the legislature might enact statutes imposing standards to be applied by the prescribed adjudicator in ordering the settlement of at least the more common subjects of such labor disputes. But by what principles, other than political expediency, would the legislature be guided in establishing such standards? "Compulsory arbitration" would inevitably manifest the evil of government by men and not by law. Moreover, "compulsory arbitration" would soon result in the disappearance of bargaining between employers and organized labor, for the party favored by the foreordained standards in a specific dispute would subject the other party to the compulsory procedure, instead of attempting painstakingly to work out a voluntary agreement.

Instead of enacting rigid standards for judicial or quasi-judicial settlement of labor contract-negotiation disputes, the legislature might create a peacetime equivalent of the National War Labor Board and authorize it to be the final arbiter of such disputes. If such a board or commission or agency were to promulgate a set

\footnotetext{
12 "Novel" demand means a demand as to which there exists no precedent within the industry or area. Perhaps the main reason for labor's hesitation to accept even voluntary arbitration as a universal remedy for contract negotiation disputes is its fear that by this process it will not be able to achieve what it regards as "social gains," such as an annual wage, health benefits, etc., because any acceptable arbitrator will be highly conservative in his decisions as to such matters.
} 
of standards, or arrive at them by a series of precedent-making decisions, substantially the same undesirable conditions would result as from a legislative code. And if the board should try to avoid these pitfalls by proceeding strictly on an ad hoc basis, thus keeping potential litigants in a state of complete uncertainty, it would soon find itself in an untenable position. Either it would be driven out of existence by charges of inconsistency, partiality and prejudice, or. it would atrophy from inactivity.

A still more vital objection to "compulsory arbitration" of disputes concerning the establishment of terms and conditions of employment is that such a process would be more inclined to provoke disputes than to eliminate them. The employment relationship is a continuing one. In an ordinary sale an exchange of property for price is consummated and the parties separate until such time as they may wish to engage in another transaction. But an individual worker does not sell his labor in one clump to his employer. He delivers it throughout each minute of an indefinite and often prolonged period of employment; and what the employer receives is a variable, for the quality. of the work delivered will inevitably be affected by the worker's attitude toward his job, his boss, and the terms and conditions of his employment. Employment is somewhat like marriage, even if it be a shot-gun wedding. The employer and his employees have to live together. When they negotiate as to terms of employment, the important effort is not merely to exccute $a$ contract; it is to arrive at a set of working conditions which they will find mutually satisfactory as they go on living together. A procedure to which either the employer or his organized employees do not willingly submit, and out of which there emerge for the employment relationship decreed terms with which one of the parties (or possibly both) does not agree, is ill-devised to produce a mutual feeling of fair treatment. Without such a feeling low morale, petty bickering, suspicion, distrust, and their disruptive effects are unavoidable. At best the losing party will insist upon a highly technical interpretation and application of the order in an effort to minimize its detrimental effects, and will strive to bring about new or border-line conditions as a basis for challenging its continued applicability. Litigation will multiply, and increasingly the time and attention of both employer and employees will be focused on court or board proceedings to the detriment of their joint task of production. ${ }^{23}$

Finally, the major objection to any form of "compulsory arbitration" is that its enforcement would be impracticable. The urge for a compulsory settlement of labor disputes derives from a desire for an antidote to strikes. A law providing a compulsory procedure for establishing disputed labor terms is infinitely worse than no such law, unless it is enforced. Successful defiance of the decree of any lawenforcing agency is a social evil, as it encourages disrespect and disdain for all law and legal procedure. If the authorized court or board were to direct a body of

2a The magnificent record of the National War Labor Board might seem to refute these dire predictions. But the very fact that it operated under wartime conditions of intense patriotism, government financing, and extreme labor shortages explains the absence of significant resistance to its orders. Former members of the board are themselves among the foremost opponents of a prolonged extension of such compulsory procedures to a peacetime economy. 
employees to work for, and the employer to pay, stipulated wages, how could such a decree be made to accomplish its purposes of precluding an interruption of production, if either the workers in concert refused to work for the designated rates of pay, or the employer refused to keep his plant open on the terms decreed? It is possible, barring constitutional objections to "involuntary servitude," that the recalcitrant workers might be induced by threats of jail sentences or other penalties to work, but not to work effectively. It is possible, barring constitutional objections to the taking of private property "without due process of law," that the government might seize and attempt to operate the plant of an intractable employer. But neither of these sanctions could be widely utilized without drastic encroachments upon our system of free enterprise. Any attempt on a national scale to direct and enforce wage rates (to say nothing of other terms of employment) would open a Pandora's box of government regulation, for the government would find that it could not avoid concerning itself with such related matters as prices and profits. ${ }^{24}$

\section{V}

\section{The Merits of Voluntary Arbitration}

It has been indicated that there are four principal reasons why "compulsory arbitration" will not provide an acceptable solution to the problem of finding means for the peaceful settlement of deadlocks between an employer and a union arising out of labor contract-negotiation disputes. They are: ( $\mathrm{I}$ ) the minimizing effect of "compulsory arbitration" upon genuine bargaining by the disputants; (2) the absence of standards without which the adjudicator could not avoid being (or at least seeming to be) either arbitrary or reactionary; (3) the tendency of "compulsory arbitration" to increase rather than to diminish disputes, because of the probable reluctance of at least one of the parties to "live with" the adjudicator's order; and (4) the impracticability of enforcement of the decree. In view of the belief heretofore expressed, that the most hopeful prospect for industrial peace lies in recourse to voluntary arbitration, it may well be asked whether these objections do not apply equally to voluntary arbitration. The answer is to be found in an analysis of this institution.

Arbitration being a voluntary procedure, the first essential is an agreement of the parties to arbitrate. Hence arbitration, far from representing a breakdown of collective bargaining, is an outgrowth of it. Normally, arbitration of the terms of a disputed labor agreement results from a special stipulation entered into by the parties. If neither party is under any duty to submit an eventual deadlock to arbitration, an effort to achieve a mutually satisfactory settlement through extensive collec-

\footnotetext{
"With respect to "grievances" (as distinguished from labor contract-negotiation disputes) redress may now be sought through ordinary court procedures for the settlement of alleged breaches of contract. Judges in courts of general jurisdiction are, however, seldom well trained in labor relations or adequately acquainted with industrial problems. If their functions were confined to this category of labor disputes, special labor courts or boards might be preferable to existing judicial instiutions, especially if speed and flexibility of decision, now unattainable, could be achieved by them.
} 
tive bargaining usually precedes the execution of an arbitration stipulation. If, however, at the very outset of contract negotiations the parties are already bound by a prior agreement to submit future unresolved disputes to arbitration, this agreement may have somewhat the same minimizing effect upon the process of collective bargaining as a statutory requirement of "compulsory arbitration." But anticipatory agreements to arbitrate labor disputes other than "grievances" are extremely rare, and in any event do not have the indefinite duration of a statute establishing a system of "compulsory arbitration."

One of the chief merits of voluntary arbitration, as contrasted with any compulsory procedure, is that the disputants jointly control the selection of the person or persons to be entrusted with authority to decide the issues in dispute. When the deadlock relates to the substantive provisions to be incorporated into an agreement between the employer and the union (and is not merely a "grievance" or other dispute as to the application of an existing contract), a common, and a preferable, practice is to utilize a board of arbitrators instead of a single umpire. For such a board each of the parties designates one or possibly two members, and then an impartial chairman-is selected. ${ }^{25}$ When such a board functions efficiently, arbitration is more than just an outgrowth of collective bargaining, it is a continuation of the bargaining process. After the case has been heard and the record is complete, the members of the arbitration board go into executive session, and the designees of the employer and of the union, with the aid of the chairman, engage in much the same process of discussion and negotiation as is represented by genuine collective bargaining at its best. In my own experience as an arbitrator, I have been quite surprised to discover that in a majority of cases, each involving a complex of contract issues, the members of such tri-partite boards of arbitration have been able to arrive at unanimous decisions on all issues.

Furthermore, in voluntary arbitration the very fact that the process is a consensual one enables the parties to overcome to some extent that absence of acceptable standards which plagues "compulsory arbitration." In jointly selecting the arbitrator, the parties act with knowledge of his character, his training, his experience and his predilections. Thus to the extent that his standards may be anticipated the disputants mutually adopt them as their own. Moreover, the authority of an arbitrator springs solely from the arbitration agreement of the parties, and in that agreement they can jointly establish certain standards by which he is to be controlled. For example, they can stipulate whether or not "ability to pay" is to be a factor in determining wage rates; they can define the industry and the area within which interplant comparisons may be made; and in various ways they can control the matter of

${ }^{28}$ Usually the representatives of the employer and the union either select the chairman by joint agreement, or they delegate his selection to the other board members designated by them. If the partica cannot reach an agreement upon the choice of a board chairman by either of these methods, they may then appeal for suggestions to such bodies as the U. S. Conciliation Service, the American Arbitration Aseciation, or 2 state mediation board, or they may authorize one of these bodies, or a trusted federal or state judge, to make the selection. 
standards to an extent not possible under a compulsory procedure, where one disputant can haul the other before a judge or administrative agency having authority to order settlement of the issues in dispute in accordance with the provisions of a statute from which alone such authority is derived.

In "compulsory arbitration" the decision is equivalent to a judgment rendered by a court, and the losing party will frequently feel aggrieved and justified in evading the result as much as possible. The outcome of a voluntary arbitration, however disappointing the award may be to one or both of the parties, is not nearly so likely to have this dispute-generating aftermath. In agreeing to arbitrate, the disputants in effect execute a contract with some blank terms in it; they authorize the arbitrator $^{2 B}$ to fill in the blanks for them, and what he fills in becomes their contract. Thus the same morality that recognizes the sanctity of a contract also sustains an arbitration award. A governmentally enforced decree does not enjoy a similar ethical standing.

As far as enforcement is concerned, experience indicates that, in labor disputes, defiance of an order emerging from compulsory proceedings is far more frequent than non-compliance with the award of an arbitrator whose authority is created by joint agreement of the disputants. There are familiar instances of defiance by workers and their unions of court injunctions, and of non-compliance by employers with orders of such administrative agencies as the National Labor Relations Board and the National War Labor Board. But there have been very few occasions upon which either the losing union or the losing employer has failed to abide by the outcome of voluntary arbitration proceedings. Should enforcement become necessary, whatever sanctions are practicable in the case of "compulsory arbitration" can also be made available with respect to voluntary arbitration.

If, as the foregoing analysis has indicated, the merits of voluntary arbitration far outweigh those of "compulsory arbitration" as a method of settling deadlocks over terms and conditions of employment, it would seem apparent that the public.interest lies not in seeking more effective sanctions for the enforcement of governmental decrees, but in encouraging and facilitating resort to voluntary arbitration by both employers and unions.

\section{VI}

\section{The Obstacles to Voluntary Arbitration}

Unquestionably the traditional reluctance of employers and unions to arbitrate contract-negotiation disputes stems from suspicion as to the impartiality and competency of any arbitrator whom the other side may propose, and from understand-

"Throughout this article the term "arbitrator" is used to refer either to a sole arbitrator or to the majority of a multiple board of arbitrators. Occasionally an arbitration stipulation establishing 2 multiple board provides that the chairman alone shall render the decision, if at the conclusion of the proceedings the other arbitrators are unable to agree upon a solution. This is done in an effort to avoid pro forma dissents. In "grievance" arbitrations such a procedure may have some merit (although 2 single arbitrator would be adequate), but in the arbitration of contract-negotiation disputes it is, in my opinion, preferable to provide for decisions by majority vote of a tri-partite board. 
able hesitancy to agree to a "blind date" with an arbitrator to be designated by some third person. If voluntary arbitration is to become an effective final stage in a process of genuine collective bargaining, some way must be found to overcome this stumbling block.

Fortunately; a far greater number of competent arbitrators is available today than ever before. During the war hundreds of public members of boards, commissions, and panels, under the auspices of the National War Labor Board and other agencies, had the opportunity and responsibility of dealing with all phases of labor disputes day in and day out throughout the nation. In this way scores of these public representatives have acquired a practical experience in labor relations which sometimes transcends even that of management and union negotiators.

The real problem is no longer a lack of competent, impartial arbitrators. What is needed is a change in the outlook of both company and union representatives concerning the qualifications of an arbitrator. It is a fair presumption that, although they may be deadlocked over certain matters that may be of vital concern, each of the contracting parties wants a contract that both will thereafter find to be reasonably acceptable. Self-interest would therefore indicate that each party should make no effort to induce the other to agree to an arbitrator from whom a biased, lop-sided award might secretly be expected. Moreover, a greater willingness to take some chances in the selection of an arbitrator must be developed by both sides.

Honesty and fearlessness are, of course, requisites for any arbitrator. An agreeable personality is highly desirable. In addition, astuteness, and experience which will enable him readily to comprehend and to evaluate the respective contentions, are important assets. But all too often the parties, while insisting upon these qualities, also appear to expect their choice to fall upon a man who is a complete blank with respect to political, social, economic or other predilectionsl. This attitude reminds one of the saying, "Why be difficult when with just a little more effort you can be impossible?"

In every community there are some men whose training has been such as to develop in them intellectual honesty-a capacity for suppressing preconceptions and arriving at conclusions on the basis of objective considerations, especially when confronted with the responsibility of deciding the fortunes of others. ${ }^{27}$ No arbitrator is infallible. Mistakes and even prejudices will from time to time prove detrimental to one of the parties. But it is easy to magnify the dangers and to forget that the alternatives to arbitration as a solution of a deadlock-strikes, lockouts and their concomitants, or possibly governmental intervention-can be far more devastating.

Another impediment to the adoption of arbitration as a method of arriving at terms and conditions of employment is that by the time the need for arbitration develops the disputants may not be in a temper to agree on anything. When the

\footnotetext{
${ }^{27}$ If adequate tests are developed and properly administered, a body such as the United States Concilia. tion Service, the American Arbitration Association, or a state mediation board can render important service to disputants by sifting out potential arbitrators -worthy of their consideration.
} 
representatives of an employer and of a union have engaged in extensive negotiations as to the substantive provisions of a proposed trade agreement, and when they finally become deadlocked over certain of these matters despite prior concessions on each side, a "last ditch" attitude may have been built up which will minimize the likelihood of agreement upon the details of arbitration procedure.

Where a sincere effort at agreement through collective bargaining has been made, the deadlocks that emerge may generally be accounted for in one of two ways: either one side regards the final offer of the other on the remaining issues as unreasonable, or the final bffer of the other side, though not in fact regarded as unreasonable, is unacceptable for collateral reasons. ${ }^{28}$ Having arrived at what are believed to be sound reasons for resisting further concessions concerning the substantive terms of the bargain, a party may then make the mistake of accepting these "sound reasons" as also justification for refusing to agree upon a process different from direct negotiation for reaching a settlement. In as much as agreement to the substituted process is not agreement to the substantive terms proposed, different considerations should affect each. Indeed, the more unreasonable one considers the ultimate position of his adversary, the more willing he might be expected to be to submit the dispute to the judgment of an impartial third person. ${ }^{29}$

Finally, some employers and some unions are "gun-shy" with respect to arbitration because of a past unhappy experience, which may have resulted from a failure to appreciate the nature of arbitration proceedings. I believe that when the parties to labor contract negotiations become deadlocked, they should readily agree to arbitrate. But by "arbitrate" I do not mean merely that they should get up before some casually chosen third person and seek to influence him by heat and emotion rather than by facts and reasoning. Arbitration, though less formal, is somewhat like a court proceeding. It is always highly desirable to enter into a written stipulation to arbitrate. There being no pleadings as in litigation, the stipulation should contain a detailed statement of the issues in order that there may be no misunderstanding as to the jurisdiction of the arbitrator. In formulating the stipulation to arbitrate the parties should make every effort to agree upon the inclusion of standards, conceded facts, or any other matter that would facilitate the work of the arbitrator.

Above all, before presenting the case to the arbitrator each side should be prepared to the hilt: relevant and sufficient facts should have been assembled; where they will be helpful, charts, diagrams and tables should have been prepared; the examination of witnesses should have been carefully thought out. And the chief reliance should be on facts rather than upon bald argument. When arbitration pro-

${ }^{28}$ At times a union representative will refrain from indicating his agreement for fear of being charged by his constituents with having "sold out"; sometimes the employer representative will withhold his assent because the issue in question has become a matter of "principle" with employers generally, and a sense of class loyalty holds him in line.

${ }^{20}$ Arbitration is also sometimes a face-saver for those who find themselves in an untenable position with no graceful exit. 
ceedings are conducted in this spirit and with this degree of preparation, it becomes almost impossible for a competent, conscientious arbitrator to do substantial injustice to either party.

I believe that there are no more important people in the United States today than those, who, on both sides of the table, have been entrusted with doing the bargaining as to terms and conditions of employment in just a few industries, such as coal, oil, steel, and transportation. Their importance lies not in the fact that their decisions can materially affect the people and the interests they respectively represent, but in the extent to which their conduct may forever affect the freedom of millions whom they do not represent. If collective bargaining does not work in these key industries, if the negotiators are unable to agree upon labor relations, or even upon a procedure for resolving disputed issues, if much needed production is seriously and frequently curtailed while the parties sulk in their corners (even if they do not engage in miniature civil war), government will surely intervene, a succession of regulations, controls and dictates will follow, and freedom of enterprise will become a historic memory.

The responsibility resting upon a handful of negotiators is colossal. Stupid men do not achieve such positions; and no sane man would consciously, through either stubbornness or greed, invoke so great a national disaster. I thoroughly believe that those who occupy these vital posts in both labor and industry have every reason to desire the perpetuation of a system of freedom of enterprise, of freedom from state dictation. I am not so sure that they have yet come to realize the terrible concatenation of events that willful or selfish attitudes on their part can project. But this they must be brought to understand; and when they do, collective bargaining will on both sides be carried on with a much greater eagerness for agreement. Few unresolved disputes can survive negotiations conducted in this spirit. As to these occasional deadlocks the negotiators will be fully conscious of their grave responsibility (') society. One may confidently predict that from such a bargaining atmosphere voluntary arbitration will emerge as the generally accepted final step in labor contract negotiations. 